
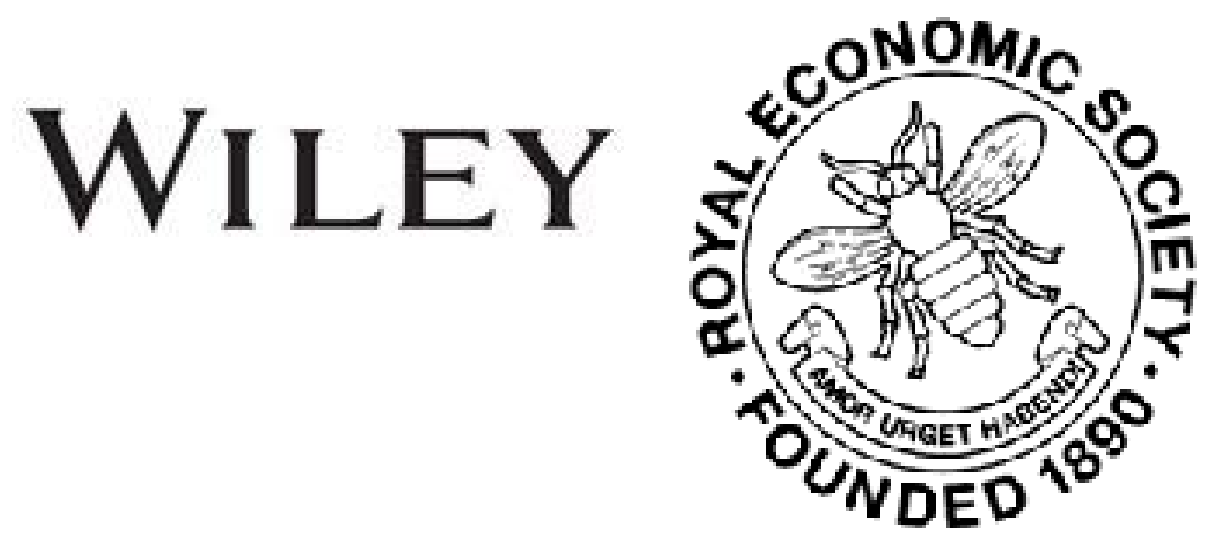

\title{
The Present Position of the Land Tax
}

\section{Author(s): A. Hook}

Source: The Economic Journal, Vol. 15, No. 59 (Sep., 1905), pp. 374-380

Published by: Wiley on behalf of the Royal Economic Society

Stable URL: http://www.jstor.org/stable/2221395

Accessed: 27-06-2016 03:22 UTC

Your use of the JSTOR archive indicates your acceptance of the Terms \& Conditions of Use, available at

http://about.jstor.org/terms

JSTOR is a not-for-profit service that helps scholars, researchers, and students discover, use, and build upon a wide range of content in a trusted digital archive. We use information technology and tools to increase productivity and facilitate new forms of scholarship. For more information about JSTOR, please contact support@jstor.org.

Wiley, Royal Economic Society are collaborating with JSTOR to digitize, preserve and extend access to The Economic Journal 


\section{THE PRESENT POSITION OF THE LAND TAX}

THE history of the Land Tax falls naturally into two parts, the period before and that subsequent to Pitt's Land Tax Act of 1798. The most interesting features of the earlier period were (1) the inclusion of personal property as a subject of charge, and (2) the fixing of the amount to be raised by determining the sum to be contributed by each parish or place. Under the Act W. and M. c. 4 (1) tax was levied on real property at $4 s$. in the $\&$ on the rack rent, on offices (except naval and military), and on personal property (except farm stock and household goods) at $24 s$. per $£ 100$ capital value. The valuation made under that Act produced a sum of $£ 1,922,712$. So far as personal property is concerned, the history of the tax bears out the economic objection to this kind of impost that it lends itself easily to evasion, and that the revenue from such a source must be subject to a steady decrease. Although the Act of William and Mary made personal property the main object of the tax, and looked only to land to supply the residue of the sum required, yet during the next few years the produce of the tax steadily dwindled, owing to the fact that personal property gradually fell out of assessment as the result of false returns and indifferent administration. So considerable was the loss of revenue from this cause that in 1697 the method of charging by a rate in the pound was dropped, and Parliament fixed the amount which each parish should raise. Even that measure was insufficient to cure the radical defect in the tax, and the evil grew to such an extent that the yield from personal property, which formed the main provision of the Act of 1693, fell by 1798 to $£ 130,000$, and by 1832 to $£ 5,214$. The land tax, so far as personal property was concerned, was abolished in 1833, it being found practically impossible to keep such property in assessment. The experience of the English tax is repeated wherever a tax on movable property has been attempted. Dealing with the tax in the United States, Professor Bastable remarks that although 
an elaborate series of questions is addressed to each individual, " still the universal experience is that the greater part of personal property is not returned. ... The defects of the American property tax are, it would appear, beyond remedy, and therefore it may be anticipated that it will in the future be transformed into a land tax . . . . and perhaps finally into an income tax." This remark derives singular interest from the history of the English tax on personal property.

The system of quotas was introduced in 1697. It was an attempt to counteract the inherent defects of a personal property tax, and was adopted as the only means of maintaining the yield of the tax in face of the persistent tendency of personal property to slip out of assessment. Its effect was a very unequal distribution of the tax. Parliament determined the total amount to be raised each year; and the proportion of this amount to be provided by each parish or place was fixed according to the relative valuation of each parish as assessed under the Act of 1693. The inequalities of that first valuation (themselves very considerable) were greatly magnified as time went on. Some parts of the country increased in wealth while others fell away. Yet such parishes continued to pay the same proportion of the total tax as in 1693 . It is obvious that this system of quotas could only be tolerable where revaluation was made at short intervals; and this fact was repeatedly urged by public men prior to 1798 , but without effect. The inequality of the burden proceeded to so ludicrous a length that, prior to the Finance Act of 1896, the pound rates varied from about one-fifteenth of a penny to $4 s$. in the $£$ in different parts of the country. The method of taxation by quotas or apportionment is long discredited; but it still survives in the English Land Tax, and the history of that tax furnishes ample testimony of the defects of that system.

The Land Tax Act of 1798 (38 Geo. III., c. 5) proceeded on similar lines to previous enactments. But the later Act of that year (38 Geo. III., c. 60) effected a remarkable change in the position of the tax. Until 1798 the tax was an annual one, and required an annual vote. It was accordingly capable of modification in amount and method year by year. The Act last mentioned, however, made the charge permanent so far as it related to real property, fixing the quotas of each parish or place in perpetuity. Having thus turned the tax into a rent-charge, having by a stroke of the pen appropriated to the State a considerable proportion of the rents 
of real estate, Pitt proceeded to resell such proportion to the original owners by allowing them to redeem the tax on payment of a certain capital sum. The cause of this revolutionary measure is to be found in the financial difficulties of the time, and need not detain us here. The principle which it established was, however, of far-reaching importance. The conversion of the annual tax into a permanent rent-charge was, in fact, an instance of land nationalisation by " confiscation" on a very considerable scale. The capital value of the rent-charge thus appropriated by the State amounted to about $£ 70,000,000$. A similar operation now on the same relative scale would yield to the State a capital sum of about $£ 1,000,000,000$, drawn solely from real property. Nowhere in history can we find a more emphatic assertion of the principle that the landowners of this countrv have no absolute property in the land they "own," but hold it merely on trust for the State, a trust which the State is able to resume at its pleasure. A tax which lays down such a principle as this is certainly deserving of close attention.

The provisions for redemption introduced for the purpose of raising money vitally affected the position and character of the tax. The valuable elasticity the tax might otherwise have possessed was completely destroyed. If Pitt had only made permanent the pound rate instead of the quota! It would have destroyed his redemption proposals, although even then the tax might have been redeemed on liberal terms for a fixed number of years, but what a golden shower would now be falling year by year into the national exchequer! The yield of the tax was, unfortunately, petrified for all time, and the country lost the opportunity of participating in the growing value of the property on which the tax was originally charged. The extent of this loss may be appreciated from the fact that, whereas the gross yield of the tax was fixed at under $£ 2,000,000$ (the maximum rate being $4 s$. in the $£)$, the present annual value of the real property in the country amounts to about $£ 250,000,000$, needing to produce the above gross yield a rate of $2 d$. in the $£$. Pitt's redemption proposals were so far successful in their immediate purpose that in 1798 and 1799 about $£ 10,000,000$ was raised in this way, no less than $£ 435,888$ of the gross quota, $£ 1,905,077$, being extinguished. The amount of the annual redemption quickly dropped, and it is now approximately $£ 2,000$ a year. From 1798 to 1904 the total redemption amounted to $£ 934,523$, leaving the present net quota at $£ 970,554$. 
From 1798 till 1896 the scheme of the tax remained unaltered. In the latter year, however, some attempt was made to redress the enormous inequality to which the system of fixed quotas had given rise, and it was provided that the rate should in no case exceed $1 s$. in the $£$ on the annual value of the properties charged. The excess of the quota in any parish above the yield of $1 s$. in the $£$ has since been written off yearly. In the year 1903-4 the concession affected 3,193 parishes, and the sum written off reached $£ 87,950$. Economically it is difficult to defend the step by which the State voluntarily surrendered a portion of its interest in these properties. Where such property had changed hands subsequently to 1798 allowance for the perpetual land tax must have been made in the purchase price, and the subsequent remission of part of the tax constituted an appreciable gift to the new owners. From the nature of the property affected such instances were probably rare. In any case the economic lapse may be considered as sufficiently excused owing to the unequal burden of the tax; and the measure also indicated a desire on the part of the Government to restrict the operation of the tax, and perhaps pointed to its ultimate extinction.

In the same year, 1896 (59-60 Vic. c. 28) it was also provided that where the rate was under $1 \mathrm{~d}$. in the $£$ such rate should be increased to $1 d$., and the excess so collected applied to the earlier redemption of the quota in those parishes. In 1903-4 688 parishes were affected, and in all those the tax will probably be extinguished at an early date.

In 1898 (61-2 Vic. c. 10) a still more singular change took place. The Land Tax, which since 1798 has been strictly a rentcharge, and has entered accordingly into all contracts of sale, was treated as an annual tax subject to exemption or abatement in the same way as the Income Tax itself. Owners with incomes not exceeding $£ 160$ (and so exempt from income tax) were exempted from land tax also; while those whose incomes did not exceed $£ 400$ (and who were, therefore, entitled to an abatement of $£ 160$ for income tax purposes) were charged only half the land tax. Here, again, the measure was indefensible, having regard to the real nature of the tax, and the reason for the step must be sought outside the field of economics. The effect of these remissions amounted in 1903-4 to $£ 143,545$.

The position of the tax on March 25th, 1904, is shown by the Commissioners of Inland Revenue as follows :- 
The aggregate of the unredeemed quotas on March 25th, 1904, in England, Wales and Scotland (the tax does not extend to Ireland)

Amount of land tax collectible for broken periods in cases where redemptions were effected during the year 1903-4 ...

Deduct amounts remitted in 1903-4 :- $\quad £$

Remission of tax above $1 s$. in $£ \ldots \quad \ldots \quad 87,951$

$\begin{array}{llllr}\text { Ditto (exemptions) } & \ldots & \ldots & \ldots & 115,400\end{array}$

$\begin{array}{lllll}\text { Ditto (abatements) } & \ldots & \ldots & \ldots & 28,145\end{array}$

Amount written off as charged on

Government property

233,046

Amount collectible for year 1903-4

$£ 738,695$

Original number of parishes with separate quotas in

1798 in England and Wales ... ... ...

Quotás extinguished since $1798 \ldots \ldots \quad \ldots \quad \ldots \quad \ldots$

Number of parishes at present charged with separate

quotas in England and Wales $\ldots \quad \ldots \quad \ldots$

Average amount collectible per parish ... $\quad \ldots \quad \ldots \quad £ 446$

The actual cost of collection cannot be exactly ascertained from any figures appearing in the annual statistical returns, but, allowing a reasonable proportion of the general expenses of the Inland Revenue Department, and taking into account the surplus land tax rewarded to the assessors under 53-4 Vic. c. 21 , it may be safely assumed that the total cost of raising the revenue referred to does not fall short of $£ 100,000$.

The above brief statement of the present position of the tax makes no reference to sundry minor features (such as the redemption of the tax without exoneration), which merely add further complications to an already confused system,

The main features of the tax to-day are : a small and steadily diminishing yield ; a relatively heavy cost of collection, which will not diminish in the same ratio as the produce of the tax; a great inequality in the rate, at present ranging from $1 d$. to $1 s$. in the $£$; its numerous complications resulting from remissions, \&c.; its complete want of elasticity ; the obstacle it offers to any comprehensive treatment of the question of land taxation; and, finally, its permanent nature. The last-mentioned fact is, under 
the circumstances, the most objectionable of all; and there will probably be no two opinions as to the desirability of removing such an anomalous and incongruous system from the statute-book. It seems impossible that the impost should be allowed to drift on through the ages, dragging its heavy load of objections, and yielding an ever smaller return, till at some distant time it dies through the sheer impossibility of preserving the records of the year 1798. Sooner or later a term must be fixed to its life. Whatever may be the process of extinction, whether by merely terminating it after a fixed number of years, or by repealing it forthwith, or by some course of compulsory redemption, numerous objections are certain to present themselves. It will be for the Government of the time to choose the least of these evils. The essentials of any method that may be adopted are at least (1) that the tax should be extinguished within a relatively short period; (2) that it should involve as little loss and disturbance to the revenue as possible; (3) that its concessions to land tax payers should not be so great as to create feeling among those who have already redeemed the tax; (4) that it should not impose too heavy a burden upon the payer of the tax during the period of extinction.

The following method of extinction would probably accord with these essentials as closely as any : (1) the tax to be fixed at its present figure without new assessments or revaluation; (2) a triple assessment (i.e., three times the tax at present charged), to be made for each of the next ten years (or less if the quota is extinguished at an earlier date); (3) at the end of ten years the tax to cease. The effect of this proposal may be shown approximately as follows :-

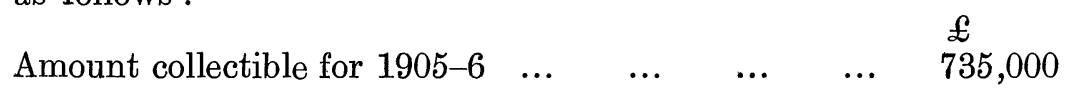

The triple assessment to be paid yearly $\quad \ldots \quad \ldots \quad 2,205,000$

Of this triple assessment one-third to be treated as revenue

$\begin{array}{llll}\ldots & \ldots & \ldots & \ldots\end{array} \quad \ldots \quad \ldots$

735,000

And two-thirds as a sinking fund for redemption ...

At the end of ten years the sinking fund, with interest at three per cent., will amount to about ...

... $17,000,000$

This sum, if used to extinguish $2 \frac{1}{2}$ per cent. stock at an average price of (say) 92, will reduce interest

$\begin{array}{cccccccc}\text { on debt by } & \ldots & \ldots & \ldots & \ldots & \ldots & \ldots & 462,000 \\ \end{array}$

$\begin{array}{llllll}\text { Add cost of collection, about } & \ldots & \ldots & \ldots & \ldots & 100,000\end{array}$ 
To this some addition should be made on account of the transfer of the labours of the present staff to more productive sources of revenue, and the total saving might be put at $\ldots \quad \ldots \quad \ldots \quad \ldots$ $\begin{array}{llllll}\text { As against the present yield of } & \ldots & \ldots & \ldots & \ldots & 600,000\end{array}$ The total annual loss would, therefore, not exceed ... $\quad \overline{£ 135,000}$

And this sum is subject to considerable discount owing to the fact that the percentage of the cost of collection is likely steadily to increase.

As regards the amount of the loss, it may be pointed out that the remissions of 1896 and 1898 involved a diminution in revenue of about $£ 220,000$; so that relatively to the advantage gained the above method of extinction would be inexpensive. In the second place the advantage to the redemptioner would be considerable. He would pay 'twenty years' purchase, spread over ten instalments, a great gain compared with the present limit of thirty years' purchase for redemption. Thirdly, the burden on the redemptioner would not be excessive. The average rate of the tax at present is about $4 d$. in the $£$. The average of the triple assessment would be about $1 s$. The maximum would reach $3 s$. (or $1 s .6 d$. if the taxpayer's income did not exceed $£ 400$ ). The adoption of the proposal would at once stop the present process of redemption, and would forthwith release part, at least, of the land tax officials for other work. Moreover, the Exchequer would continue to receive its present income from the tax for the next ten years, together with the saving on the debt cancelled each year; while at the end of the ten years the loss of revenue from the final extinction of the tax would be almost balanced by the saving effected. Finally, the proposal would involve no principle not already adopted either in the Act of 1896 or in that of 1898.

A. Hook 